\title{
Developing Payment for Ecosystem Services Scheme on Pari Island Kepulauan Seribu
}

\author{
Nurul Hidayati ${ }^{1}$, Mahawan Karuniasa ${ }^{1, *}$, Mufti Petala Patria $^{2}$, and M. Suparmoko ${ }^{3}$ \\ ${ }^{1}$ School of Environmental Science, Universitas Indonesia, Salemba Raya No. 4 Jakarta 10430, \\ Indonesia \\ ${ }^{2}$ Department of Biology, Universitas Indonesia, Depok 16424, Indonesia \\ ${ }^{3}$ Faculty of Economics and Business, Universitas Budi Luhur, Ciledug Raya Jakarta 12260, Indonesia
}

\begin{abstract}
Pari Island is a tourism area and the number of tourists has increased each year. It decreases the quality of the coastal ecosystem. However, major funding is required to maintain the quality. This study using literature review explains the value of ecosystem services and the PES scheme. The total willingness to pay, that explains the value of ecosystem services, is higher than operational budget. It indicates PES scheme can be used as an alternative way to cover operational cost. The PES scheme that can be implemented on Pari Island is between local forum as ecosystem services provider and tourists of Pari Island as user. This research contributes to the development of PES to protect the coastal ecosystem of Pari Island. This study also informs the importance of beach for Pari Island and the great negative economic impact if the beach is damage.
\end{abstract}

\section{Introduction}

Coastal and marine ecosystems, comprised of mangroves, seagrass beds, coral reefs, and sandy beaches, provide ecosystem services which benefit to people, including provisioning, regulating, cultural services, and supporting services [1]. While for some ecosystem services (e.g. food and raw material) market exists and function well, many ecosystem services are considered invaluable by the market system. Furthermore, those ecosystems are currently being threatened from anthropogenic and non-anthropogenic [2, 3].Based on this backdrop, payment for ecosystem services (PES) can be used to protect the environment[4].

The tourism industry is significant for Indonesian economy, accounting for $5 \%$ of Indonesia's GDP in 2017 [5]. In addition, beach tourism contributes $10 \%$ of total foreigntourism. Pari Island, located in Kepulauan Seribu, is one of the beach tourism areas. It has been developed as a natural tourism area since 2012. The number of tourists in 2017 increased by 131.692 people than in 2011 [6]. The increase of tourists will decrease the quality of the environment $[7,8]$.To maintain the quality of coastal ecosystems, major financial funding is needed. However, Pari Island received no direct funding from the

\footnotetext{
*Corresponding author: mahawancac@yahoo.com
} 
national or local government. Because of this reason, market-based solutions for conservation, including PES can be one source to support the financial needs [9].

PES can be defined as voluntary transactions between service usersand service providersthat are conditional on agreed rules of natural resource management for generating services [9]. PES is interesting because it has an element of innovation for conservation. PES are seen as innovative, that is: supporting proactive action, replicate, transfer and scale, spurring competition, output-based payments, new ways of stakeholder,building unusual partnerships, tapping new sources of funding, and positive side-effects and win-wins [10]. In addition, PES may be appropriately applied on Pari Island because (1) they generate new financing that would not otherwise be available for conservation, (2) sustainable because they do not depend on government or donor financing, and (3) can be more efficient [11].

There are four phases in PES design [10]. The first one is crucial due to decision of the price to be paid for environmental services and design of scheme of PES. Therefore, the aim of this study is to understand how to estimate the value of beaches to the visitor of Pari Island and design the PES scheme to improve the quality of coastal ecosystem on Pari Island.This study contributes to theecosystem services literature due toadifferent site, estimates the economic value to support the development of PES scheme, and the scheme design of PES can be implemented by stakeholders.

\section{Materials and Methods}

Primarily this research takes a qualitative approach. We conducted a literature review of scientifically published studies. Our search focused on studies developing payment for ecosystem services in Indonesia. The paper begin with an overview of method to estimate the value of ecosystem services. We also give a brief explanation about designing PES scheme. Afterward, we focus on three different PES programs in Indonesia. These three programs are chosen based on relevance with the condition of Pari Island. They are located on coastal area and used as tourism attraction. The remaining part of the paper includes some lesson learned that need to be addressed for further progress in developing PES scheme on Pari Island.

\section{Results and Discussions}

\subsection{Value of Ecosystem Services}

To date, various methods have been developed and introduce to assess the values of ecosystem services. Contingent valuation method(CVM) is widely used to measure ecosystem values. CVM works best when the ecosystem services are close to a market [12].CVM is a stated preference approach to the valuation of amenities, and other behaviors related to environment and natural resources. This method is useful for estimating benefits and costs for environmental and natural resource policy analysis and benefit-cost analysis involving nonmarket goods and services [13].

CVM has several roles in PES program design, that is helping assess whether PES program are feasible, estimating potential welfare increases resulting from improved service provisions, providing guidance on the price to be charged to service users, and convincing policymakers that implementing a PES program is politically feasible [11]. The components of contingent valuation scenario include a description of the resource or policy context, a description of the policy or proposed change in resource allocation that will be valued, a payment vehicle, and a payment rule [13]. 


\subsection{Payment for Ecosystem Services Scheme}

Designing PES scheme requires stakeholder analysis. Stakeholder includes any and all people who have some degree of interest (including moral interests) in an issue [14]. The aims of stakeholder analysis are (a) to identify and categorize the stakeholders that may influence and perhaps transform an organization or a system, (b) to develop an understanding of why changes happen, (c) to establish who can make changes happen, and (d) to discern how to best manage [15].

Identify stakeholder is important to determine who hold a stake in the phenomenon [16]. Stakeholder identification is classified across eight categories, that is (a) geographical footprint, (b) interest, (c) influence, (d) intuition, (e) key informants and snowballing, (f) past experiences, (g) stakeholder self-selection, and (h) use of the media [14]. For PES case, we need to identify the provider and the user [9].

\subsection{Overview of the Payment for Ecosystem Services}

\subsubsection{General Description of the PES Schemes in Indonesia}

Most PES schemes in Indonesia are located in areas of forest and watershed management. The initiators of PES schemes in Indonesia come from communities, private institutions, national and international nongovernmental organizations, and the local government. They have different purposes and schemes [17]. PES scheme is recognized on the Indonesian Law on Environmental Protection and Management No. 32/2009. PES schemes can be alternative to replace the command and control system that was used in Indonesia.

\subsubsection{Developing Payment for Ecosystem Services Scheme in Raja Ampat}

Raja Ampat Marine Protected Area (MPA) has developed into a tourism area and has a positive impact in economic terms. However, a number of activities have reduced the quality of the ecosystem. Management that ensures sustainability requires economic incentives. Rum faker [18] reported total willingness to pay (WTP) of all components (diver operators, fishermen, and tourists) isRp7.139.780.000. Besides, the operational cost of environmental management in Raja Ampat MPA in one year is Rp 6.986.800.000. Therefore, WTP potential value is higher than operational cost. It shows that the ecosystem services payment could be an alternative to gain income to maintain the existing environment.

The most suitable PES scheme in Raja Ampat is between visitors (tourists and researchers) as buyer, government (UPTD-KKPD) and NGO as intermediaries or providers, and local communities as providers [19]. Furthermore, the responsibility for managing the stewardship fee is hold by UPTD-KKPD. More than 70\% of the revenue from the fee will be used to manage the MPA network, thus UPTD-KKPD is identified as the central ES seller. Besides, NGOs as partners of the MPA also play a role as the sellers. The community fund makes the community in a seller position as well.

\subsubsection{Developing Payment for Ecosystem Services Scheme in Sukabumi}


This research was done by[20]. Pengumbahan Turtle Conservation Coastal Park (KKTP4S) provides green turtle landing area as ecosystem services. Moreover, the area is used as tourism area. The turtle population rate in Indonesia decreases each year. Various attempts have been made, but still failed. Thus, the government must change the policy to save green turtle from extinction.

Based on WTP analysis, KKTP4S has a profit of Rp 558.607.297.820/year. Furthermore, the transaction cost paid by the government about Rp 2.188.450.000/year. Comparing the two results, it can be seen that WTP potential values was higher than the transaction cost. It indicates PES can be used as an alternative way to get funding for managing KKTP4S. The potential scheme can be applied in KKTP4S is through Badan Layanan Unit Daerah (BLUD) managed by Sukabumi government. Using of BLUD supervised by supervisory board. This supervision resulted efficiency, then the revenue can be useentirely for conservation and community empowerment.

\subsubsection{Developing Payment for Ecosystem Services Scheme In Jailalo, Halmahera Barat}

This research was done by Idrus [21]. Mangrove forest in West Halmahera Regency, Jailolo Sub-district is recommended to apply PES. This is because of the high utilization of environmental services of mangrove. Furthermore, PES is fully supported by the existence of West Halmahera Regency Regional Ordinance No. 4/2012 and law No. 32 in 2009 on the environmental protection and management.

The regulatory services of intrusion of seawater and the cultural services of mangrove tour could be initiated by PES. The most suitable institutional arrangementof PES in Jailolo was applied through scheme of payments between the Government to Community ( $\mathrm{G}$ to $\mathrm{C}$ ) or Community to Community ( $\mathrm{C}$ to $\mathrm{C}$ ) between subscriber PDAM (water services), tourism (tourist services) as users of mangrove rehabilitation with community groups as a provider.

Three previous studies have some similarities. First, they are in exploration phase.Sattlerpoint out that this phase usually starts with an overall situation analysis and involves collecting and analyzing relevant information for the future PES [10]. Some questions related to this phase, that is: What is the problem and can a PES provide a viable solution? Who are the potential ecosystem provider/sellers? Who are the potential ecosystem buyers? Who are the stakeholders that need to be involved?

Second, the results of WTP analysis was more than operational cost. It indicates that PES can be an alternative to support the financial needs. Third, PES schemes that can be form are $\mathrm{G}$ to $\mathrm{C}$ (Government to Community), $\mathrm{G}$ to $\mathrm{G}$ (Government to Government),or $\mathrm{C}$ to $\mathrm{C}$ (Community to Community).

\section{Conclusion}

Coastal ecosystem provide various benefit for human. Although most of ecosystem services play an important role in economy, they are still invaluable by the market system. Tourism sector in Pari Island is important for its society and the environment. On the other hand, beaches are in constant threat because of human pressure. A clear economic argument is needed to create great awareness among policymakers and the general public of the need to protect coastal ecosystem.Protecting beaches can be considered as a base conservation due to associated ecosystem, such as mangroves, seagrass beds, and coral reefs.

\section{Acknowledgments}


The authors would like to thank Universitas Indonesia for support our research under grant scheme Hibah Publikasi Internasional Terindeks untuk Tugas AkhirMahasiswa (Hibah PITTA) Research Grant Contract No. 2581/UN2.R3.1/HKP.05.00/2018

\section{References}

1. Millenium Ecosystem Assessment, Ecosystems and human well-being: Synthesis (Island Press, Washington DC, 2005)

2. J.E. Cinner, T.R. McClanahan, N. A. Graham, T.M. Daw, J. Maina, S.M. Stead, et al. J. Global Environ 22, 12 (2012)

3. M. A. Marfai. J. Quaestiones Geographicae 33, 107 (2014)

4. S. Wunder, Payments for environmental services: Some nuts and bolts (CIFOR, Jakarta, 2005)

5. Ministry of tourism, Laporan akuntabilitas kinerja Kementerian Pariwisata Tahun 2017 (Accountability report on the performance of the Ministry of Tourism in 2017). (Kementerian Pariwisata, Jakarta, 2018)

6. Badan Pusat Statistik Kabupaten Administrasi Kepulauan Seribu, Kabupaten kepulauan seribu dalam angka (KepulauanSeribu in Numbers). (BPS Kabupaten Administrasi Kepulauan Seribu, Kepulauan Seribu, 2018)

7. H. Stanchev, M. Stancheva, R. Young, R, J. J. Coast Conserv 19, 59 (2015)

8. I. Egresi, Alternative tourism in Turkey: Role, potential development and sustainability (Springer International Publishing, Cham, 2016).

9. S. Wunder. J. Ecological Economics 117, 234 (2015)

10. C. Sattler, B. J. Matzdorf, Ecosystem Services 6, 2 (2013)

11. D. Whittington, S. Pagiola. J. The World Bank Research Observer Advance Access 27, $1(2012)$

12. M. v. Belt, V. Forgie, J. Farley, Treatise on estuarine and coastal science (Elsevier, Italy, 2011)

13. J. C. Whitehead, T.C. Haab. J. Reference Module in Earth Systems and Environmental Science 3, 334 (2015)

14. R. M. Colvin, G.B. Witt, J. Lacey. J. Land Use Policy 52, 266 (2016)

15. M. B. Krupa. J. Marine Policy 71, 194 (2016)

16. M. S. Reed, A. Graves, N. Dandy,H. Posthumus, K. Hubacek, J. Morris, et al., Journal of Environmental Management 90, 1933 (2009)

17. A. Fauzi, Z. Anna. J. Ecosystem Services 6, 54 (2013)

18. M. K. Rumfaker. Analisis pembayaran jasa lingkungan di Kawasan Konservasi Laut Daerah Kabupaten Raja Ampat (A payment analysis of environmental services in Raja Ampat Marine Conservation Area) (Institut Pertanian Bogor, Bogor, 2010)

19. E, Atmodjo, M. Lamers, A. Mol. J. Marine Policy 78, 181 (2017)

20.Dwihastuti.Studi peningkatan kualitas pengelolaan kawasan konservasi habitat penyu melalui pendekatan skema pembayaran jasa ekosistem: StudikasusTaman Pesisir Pantai Penyu Pangumbahan, Kabupaten Sukabumi(Improving the management of marine turtle habitat conservation area through payment for ecosystem services scheme: Case Turtle conservation coastal park in Pangumbahan, Sukabumi) (Institut Pertanian Bogor, Bogor, 2016)

21. S. Idrus. Inisiasi pembayaran jasa lingkungan untuk kelestarian fungsi ekologi hutan mangrove di Kecamatan Jailolo Kabupaten Halmahera Barat (Initiation of payment for environmental services for ecological function preservation of mangrove forest in Jailolo Sub-district West Halmahera) (Institut Pertanian Bogor, 2016) 